J. Perinat. Med. 16 (1988) 477

\section{Hormone release by primary amniotic fluid cell cultures}

\author{
Patricia Medina-Gómez', Antonio Espinosa de los Monteros ${ }^{2}$, Juan Belmont ${ }^{2}$, and \\ Elsa Martínez ${ }^{3}$ \\ ${ }^{1}$ Department of Human Genetics \\ ${ }^{2}$ Department of Endocrinology \\ ${ }^{3}$ Department of Biochemistry \\ Instituto Nacional de Perinatología, México, D.F., México
}

\section{Introduction}

Amniotic fluid cells have been widely used in prenatal diagnosis. Three classes of cells can be identified morphologically in primary cultures of amniotic fluids from fetuses with no neural tube defect (NTD): epithelioid (E), fibroblastoid (F) and amniotic fluid (AF). In amniotic fluids from fetuses with NTD, in addition to these cells, neuroblastoid (N) and glial cells (G) are observed; by morphology alone glial cells have been grouped as $\mathrm{G}-\mathrm{E}$ due to the difficulty of differentiating them from other epithelioid cells [16].

The importance of the cell type that is being analyzed was first stressed by GERBIE et al. [4] who found different cytological and biochemical characteristics of epithelioid and fibroblastoid cells. The different characteristics of amniotic fluid cells have suggested different origins: for F cells connective tissue of either placenta or fetal skin, and for AF cells trophoblast $[10,11,18,19]$. The origin of $E$ cells has been ascribed either to fetal urine [21], amnion [17] or respiratory and intestinal epithelia [2], and for $\mathrm{N}$ and $\mathrm{G}$ cells either neuronal or glial fetal cells [16].

Recently, several papers have been published regarding the synthesis of human chorionic gonadotropin (hCG) by AF cells and not by F cells [10, $11,18,19]$. These studies have been performed on amniotic fluid samples from fetuses with no NTD and mainly in subcultures. Little attention has been paid to $\mathrm{E}$ cells, in part due to the difficulty of tripsinizing these cells.
The aim of the work reported here was to further characterize hormone release by primary cultures of amniotic fluid cells from normal and anencephalic fetuses, in order to investigate their origin and their possible use as cell models for hormone studies.

\section{Material and methods}

Amniotic fluid cells were cultured by the in situ technique and were obtained by amniocentesis due to Rhesus isoimmunization (4), anencephalic fetuses (2) and cytogenetic prenatal diagnosis (2). The number of cultures that were set up depended on the amount of amniotic fluid sent to the laboratory, which varied from $8 \mathrm{ml}$ from Rhesus isoimmunization to $60 \mathrm{ml}$ from an anencephalic fetus. (In tables II and III, cultures from the same amniotic fluid are represented as $a, b, \ldots$ f.) In all the amniotic fluids samples the karyotype was obtained by $Q$ and $G$ banding within 21 days of initiating the culture. Primary cultures were continued trying to obtain confluency and the morphology of cells was established by phase contrast microscopy. Cells from male fetuses were preferentially used in this study so there would be not doubt of their fetal origin.

The medium in which the cells had been cultured (post-culture) was collected before ending the culture. In two amniotic fluids (one from a normal fetus and one from an anencephalic) all the postculture media were collected during the culture, 
starting with the first half medium change at the seventh day, and in the cells from the anencephalic fetus even after subculture. The post-culture media (approximately $3 \mathrm{ml}$ ) were centrifuged at 1000 RPM for ten minutes and their supernatant stored at $-20^{\circ} \mathrm{C}$ until hormone assays were performed. Two controls were used: the pre-culture medium (Ham F $12+$ penicillin/streptomycin + glutamine + sodium bicarbonate $+30 \%$ fetal calf serum) and the supernatant of all the original amniotic fluids.

Due to the technical difficulties inherent in the procedures of cell enumeration, we decided to quantitate the hormone in the cultures per weight of cell protein. The cells were removed with a rubber policeman and transferred to a plastic conical tube. The cells were centrifuged and washed five times with $10 \mathrm{ml}$ of Phosphate Buffer Solution (PBS) $0.01 \mathrm{M}, \mathrm{pH} 7.2$, until a O.D. reading of 0 at $280 \mathrm{~nm}$ in the supernatant was obtained. This indicated that the protein of the culture media had been eliminated and only the cellular protein would be assayed. The cell pellet was finally resuspended in $1 \mathrm{ml}$ of PBS. Cell lysis was achieved by performing 10 times the freeze-thaw method $\left(-70^{\circ} \mathrm{C}\right.$ to $\left.37^{\circ} \mathrm{C}\right)$; the suspension was centrifuged at 3000 RPM for 10 minutes and the supernatant was analyzed by the Lowry method for quantitating cell protein [13] with a sensitivity of $0.005-$ $0.2 \mathrm{ng} / \mathrm{ml}$.
The supernatants of the original fluids and of the pre-culture and post-culture media were coded and hCG, hCS, P, PRL and E 3 were assayed in blind trials using the double antibody method and kits from Amersham laboratories. All assays were performed in duplicate; the interassay and intraassay variabilities were less than $10 \%$. The minimal sensitivities of the assays were; hCG $4 \mathrm{mIU} / \mathrm{ml}$; hCS $0.6 \mu \mathrm{g} / \mathrm{ml}$; prolactin $2.0 \mathrm{ng} / \mathrm{ml}$; progesterone 0.1 $\mathrm{ng} / \mathrm{ml}$, and free estriol $2.7 \mathrm{ng} / \mathrm{ml}$. The results were calculated from linear curves of logit $\mathrm{B} / \mathrm{Bo}$ versus $\log$ concentrations of hormone per tube. Values below minimal sensitivity were extra-polated from the linear curve.

\section{Results}

The results are summarized in tables I, II and III according to gestational age at the time of amniocentesis, reason for amniocentesis, total days in culture, days in culture before the media was collected, cell type by morphology, cellular protein, and hormone values. Unfortunately some cell protein values were below the minimal sensitivity of the assay so we could not express the hormone values per ng of cell protein.

The presence of hCG was confirmed in the postculture media of primary cultures of amniotic fluids from fetuses with no external malforma-

Table I. Hormone values in amniotic fluid supernatants from normal and anencephalic fetuses.

\begin{tabular}{|c|c|c|c|c|c|c|c|c|}
\hline $\begin{array}{l}\text { Amniotic } \\
\text { fluid }\end{array}$ & $\begin{array}{l}\text { Gestational } \\
\text { age } \\
\text { (weeks) }\end{array}$ & $\begin{array}{l}\text { Reason for } \\
\text { amniocentesis }\end{array}$ & $\begin{array}{l}\text { Fetal } \\
\text { karyotype }\end{array}$ & $\begin{array}{l}\mathrm{BhCG} \\
\mathrm{mIU} / \mathrm{ml}\end{array}$ & $\begin{array}{l}\mathrm{hCS} \\
\mu \mathrm{g} / \mathrm{ml}\end{array}$ & $\begin{array}{l}\mathrm{E} 3 \\
\mathrm{ng} / \mathrm{ml}\end{array}$ & $\begin{array}{l}\mathrm{PRL} \\
\mathrm{ng} / \mathrm{ml}\end{array}$ & $\begin{array}{l}\mathrm{P} \\
\mathrm{ng} / \mathrm{ml}\end{array}$ \\
\hline
\end{tabular}

Normal

fetuses

\begin{tabular}{|c|c|c|c|c|c|c|c|c|}
\hline 1 & 25 & Rh-Iso & $\begin{array}{l}46, X Y / \\
92, X X Y Y\end{array}$ & 215 & 0.32 & 5.5 & 143 & 74 \\
\hline 2 & 28 & Rh-Iso & $46, \mathrm{XX}$ & 132 & 0.62 & 4.2 & 180 & 98 \\
\hline 3 & 26 & Rh-Iso & $46, X Y$ & 160 & 0.12 & 3.5 & 116 & 110 \\
\hline 4 & 22 & Rh-Iso & $46, X Y$ & 310 & 0.32 & $<1$ & 190 & 140 \\
\hline 5 & 16 & Pren. diagn. & $46, X Y$ & 350 & 0.15 & 2.1 & 180 & 80 \\
\hline 6 & $15-16$ & Pren. diagn. & $\begin{array}{l}46, X Y \\
\text { t5; } 10 \text { (p15; }\end{array}$ & 390 & 0.1 & 1.05 & 80 & 100 \\
\hline \multicolumn{9}{|l|}{$\begin{array}{l}\text { Anencephalic } \\
\text { fetuses }\end{array}$} \\
\hline 1 & 17 & Anen. fetus & $46, X X$ & 310 & 0 & 1.4 & 84 & 98 \\
\hline 2 & 31 & Anen. fetus & $46, X X$ & 310 & 1.1 & 1.4 & 143 & 120 \\
\hline $\begin{array}{l}{ }^{*} \text { Pre-culture } \\
\text { medium }\end{array}$ & & & & 0 & 0.27 & 0 & 0 & 0.13 \\
\hline
\end{tabular}

${ }^{*}$ HAM F12 + Pen./Strep. + Glutamine + Sodium bicarbonate $+30 \%$ fetal calf serum 
Table II: Hormone release by cultured amniotic fluid cells from normal fetuses.

\begin{tabular}{|c|c|c|c|c|c|c|c|c|c|}
\hline $\begin{array}{l}\text { Amniotic } \\
\text { fluid }\end{array}$ & $\begin{array}{l}\text { Total } \\
\text { days in } \\
\text { culture }\end{array}$ & $\begin{array}{l}\text { Days in } \\
\text { culture } \\
\text { before } \\
\text { collecting } \\
\text { C. M. }\end{array}$ & $\begin{array}{l}\text { Cell } \\
\text { type }\end{array}$ & $\begin{array}{l}\text { Cell } \\
\text { protein } \\
\mu \mathrm{g} / \mathrm{ml}\end{array}$ & $\begin{array}{l}\mathrm{BhCG} \\
\mathrm{mIU} / \mathrm{ml}\end{array}$ & $\begin{array}{l}\mathrm{hCS} \\
\mu \mathrm{g} / \mathrm{ml}\end{array}$ & $\begin{array}{l}\mathrm{E} 3 \\
\mathrm{ng} / \mathrm{ml}\end{array}$ & $\begin{array}{l}\mathrm{PRL} \\
\mathrm{ng} / \mathrm{ml}\end{array}$ & $\begin{array}{l}\mathrm{P} \\
\mathrm{ng} / \mathrm{ml}\end{array}$ \\
\hline \multicolumn{10}{|l|}{ No. 1} \\
\hline $\mathrm{CM}-\mathrm{a}^{*}$ & 7 & 7 & - & - & 32 & 0.27 & 0 & 41 & 15 \\
\hline $\mathrm{CM}-\mathrm{b}$ & 7 & 7 & - & - & 64 & 0 & $<1$ & 44 & 18 \\
\hline CM-a I & 11 & 4 & $\mathrm{E}, \mathrm{AF}$ & - & 18.8 & 0 & 0 & 0 & 0.22 \\
\hline CM-b I & 11 & 4 & $\mathrm{E}, \mathrm{AF}$ & - & 7.0 & 0 & 0 & 0 & 0.86 \\
\hline CM-a II & 13 & 2 & $\mathrm{E}, \mathrm{AF}$ & - & $<1$ & 0.32 & 0 & 0 & 0.94 \\
\hline CM-b II & 13 & 2 & $\mathrm{E}, \mathrm{AF}$ & - & 5.1 & 0 & 0 & 0 & 0.38 \\
\hline CM-a III & 21 & 8 & $\mathrm{E}, \mathrm{AF}$ & - & 13.8 & 0 & 0 & 23 & 7.30 \\
\hline CM-b III & 21 & 8 & $\mathrm{E}, \mathrm{AF}$ & - & 28 & 0.05 & 0 & 34.5 & 6.90 \\
\hline CM-a IV & 33 & 12 & $\mathrm{E}, \mathrm{AF}$ & 33.33 & 7.0 & 0 & 0 & 0 & 0.27 \\
\hline CM-b IV & 33 & 12 & $\mathrm{E}, \mathrm{AF}$ & 33.33 & 8.7 & 0 & 0 & 0 & 0.38 \\
\hline \multicolumn{10}{|l|}{ No. 2} \\
\hline $\mathrm{CM}-\mathrm{a}$ & 33 & 7 & $\mathrm{~F}, \mathrm{AF}$ & 39.39 & 80 & 0.06 & 0 & 0 & 0.11 \\
\hline CM-b & 33 & 7 & $\mathrm{~F}, \mathrm{E}, \mathrm{AF}$ & $<5$ & 80 & 0 & 0 & 0 & 0.06 \\
\hline \multicolumn{10}{|l|}{ No. 3} \\
\hline $\mathrm{CM}$ & 27 & 7 & $\mathrm{~F}, \mathrm{E}, \mathrm{AF}$ & 96.96 & 33.3 & 0 & 0 & 0.18 & 0.1 \\
\hline \multicolumn{10}{|l|}{ No. 4} \\
\hline $\mathrm{CM}$ & 28 & 7 & $\mathrm{~F}, \mathrm{AF}$ & 96.96 & 14.5 & 0 & 0 & 0 & $<0.1$ \\
\hline \multicolumn{10}{|l|}{ No. 5} \\
\hline CM-a & 25 & 4 & $\mathrm{AF}$ & $<5$ & 5.2 & 0 & 0 & 0 & 0.62 \\
\hline $\mathrm{CM}-\mathrm{b}$ & 25 & 4 & $\mathrm{AF}$ & 10.6 & 7.8 & 0 & 0 & 0 & 0.62 \\
\hline CM-c & 25 & 4 & $\mathrm{AF}$ & $<5$ & 3.9 & 0 & 0 & 0 & 0.50 \\
\hline \multicolumn{10}{|l|}{ No. 6} \\
\hline $\mathrm{Cm}-\mathrm{a}$ & 43 & 6 & $\mathrm{~F}, \mathrm{AF}$ & 10.6 & 2.6 & 0.29 & 0 & 0 & 0.26 \\
\hline CM-b & 43 & 6 & $\mathrm{~F}, \mathrm{AF}$ & 25.75 & $<1.0$ & 0.29 & 0 & 0 & 0.35 \\
\hline CM-c & 43 & 6 & $\mathrm{~F}, \mathrm{AF}$ & 24.24 & $<1.0$ & 0.29 & 0 & 0 & 0.35 \\
\hline
\end{tabular}

$\mathrm{CM}=$ culture medium (post-culture)

* See Material and methods

tions, including the cells with a balanced translocation and two primary cultures and one subculture from anencephalic fetuses.

There was no release of hCS during long-term culture; hCS was found in very small quantitities $(0-1.1 \mu \mathrm{g} / \mathrm{ml})$ in the original amniotic fluids and no considerable increase was found during culture. E 3 was present only in the supernatant of the original amniotic fluids and was lower in the anencephalic fetus of 31 weeks than in the normal fetuses of similar gestational age.

PRL and $\mathrm{P}$ were present in the supernatant of the original amniotic fluids and in the first medium changes, most probably due to contamination of the culture media with the original amniotic fluid. In amniotic fluid No. 1, from a normal fetus (table II), PRL and P suddenly appeared at 21 days of culture and disappeared at 33 days in culture. These samples were assayed twice confirming the results. This phenomenon was not observed in the amniotic fluid from the anencephalic fetus and further study is needed to determine in which proportion of amniotic fluids it would be present. It is interesting that when the results were decoded, an association with tetraploidy in several colonies of the harvested cultured cells was found. Unfortunately the follow-up of the pregnancy was difficulted by the delivery at 27 weeks of gestation of a stillborn male fetus. The fetus was macerated 
Table III. Hormone release by cultured amniotic fluid cells from anencephalic fetuses.

\begin{tabular}{llllllllll}
\hline $\begin{array}{l}\text { Amniotic } \\
\text { fluid }\end{array}$ & $\begin{array}{l}\text { Total } \\
\text { days in } \\
\text { culture }\end{array}$ & $\begin{array}{l}\text { Days in } \\
\text { culture } \\
\text { before } \\
\text { collecting } \\
\text { C.M. }\end{array}$ & $\begin{array}{l}\text { Cell } \\
\text { type }\end{array}$ & $\begin{array}{l}\text { Cell } \\
\text { protein } \\
\mu \mathrm{g} / \mathrm{ml}\end{array}$ & $\begin{array}{l}\mathrm{BhCG} \\
\mathrm{mIU} / \mathrm{ml}\end{array}$ & $\begin{array}{l}\mathrm{hCS} \\
\mu \mathrm{g} / \mathrm{ml}\end{array}$ & $\begin{array}{l}\mathrm{E} 3 \\
\mathrm{ng} / \mathrm{ml}\end{array}$ & $\begin{array}{l}\mathrm{PRL} \\
\mathrm{ng} / \mathrm{ml}\end{array}$ & $\begin{array}{l}\mathrm{P} \\
\mathrm{ng} / \mathrm{ml}\end{array}$ \\
& & & & & & & \\
& & & & & & \\
\hline
\end{tabular}

No. 1

\begin{tabular}{lrlllcllrr} 
CM-a* & 6 & 6 & F, G-E, N - & 140 & 0 & 1.4 & 23 & 11.5 \\
CM-a I & 11 & 5 & F, G-E, N & - & 1.2 & 0 & 0 & 0 & $<0.1$ \\
CM-a II & 15 & 3 & F, G-E, N & 44.69 & 6.0 & 0 & 0 & 0 & 0.1 \\
Subculture & & & & & & & & & \\
CM-a & 19 & 4 & F, G-E & - & 13.8 & 0 & 0 & 0 & 0.1 \\
CM-a I & 21 & 2 & F, G-E & - & 0 & 0 & 0 & 0 & $<0.1$ \\
CM-a II & 28 & 7 & F, G-E & 80.30 & 11.7 & 0.46 & 0 & 0 & 0.51 \\
No. 2 & & & & & & & & & \\
CM-a & 35 & 5 & F, G-E & 25.75 & 4.8 & 0 & 0 & 0 & 0.74 \\
CM-b & 35 & 5 & F, G-E & 40.9 & 5.7 & 0 & 0 & 0 & 0.50 \\
CM-c & 35 & 5 & F, G-E, N & 33.33 & 12.0 & 0 & 0 & 0 & 0.50 \\
CM-d & 35 & 5 & F, G-E, N 31.81 & 5.2 & 0 & 0 & 0 & 0.80 \\
CM-e & 35 & 5 & F, G-E, N 40.9 & 13.2 & 0 & 0 & 0 & 0.62 \\
CM-f & 35 & 5 & F, G-E, N 54.54 & 7.2 & 0 & 0 & 0 & 0.68 \\
\hline
\end{tabular}

$\mathrm{CM}=$ culture medium (post-culture)

* See Material and methods

but no obvious external malformations were detected; necropsy reported hyperplasia of the pancreatic islets of Langerhans, hemosiderosis of liver and spleen and alveolar hemorrhage. The death was attributed to the Rhesus isoimmunization which was so severe that two in utero transfusions were necessary.

\section{Discussion}

The heterogeneity in amniotic fluid cell morphology and their hormone release in culture was confirmed. Our results were similar to those of PRIEST et al [19] and LAUNDON et al [10], which show great variability from one amniotic fluid to another, but more consistency within duplicate cultures. There seems to be no correlation between the cell protein values and hCG release of the cell per $\mathrm{ml}$, so the cell type present in culture must be critical. GERBIE et al [4] found that protein concentrations were much higher in fibroblast-like cultures, this is probably due to multilayering [16].

AF cells, although capable of synthesizing hCG [11], did not release hCS in long-term culture. hCS is synthesized by the syncytial layer [15] and loss of hCS production has been described before in long-term cultures of trophoblast cells [24]. The present study can not prove hormone synthesis and it could be argued that hCG and hCS could be released by living or dying cells, however hCG and hCS release is distinct from other hormones. hCS is not stored in secretory granules [7] and morphological and biochemical evidence in studies in vivo and in vitro suggest that the plasma membrane plays a major role in hCG secretion [8]. Hormone release or storage in amniotic fluid cells has not been studied.

In addition, there seems to be a gradient of hCG biosynthetic capability ranging from low in cytotrophoblast to high in differentiated syncytiotrophoblast [8]. KuRMAN et al. [9] suggested that during multinucleate intermediate trophoblastic cell formation there is a shift in hormone synthesis from hCS to hCG. At this respect, it is interesting to note that in AF cultures. PRIEST et al [19] found that the number of nuclei per microscope field, the percent of nuclei in multinucleated cells, and hCG levels in post-culture medium rise with time in culture. The demonstration of a recognized trophoblast-specific product (hCG) in the postculture media indicates only that there are cells of trophoblast lineage present but cannot indicate which ones they are. It is generally agreed that 
human cytotrophoblast does not possess any significant hormonal secretory activity so dependence on such hormonal markers may therefore be expected to lead to a significant number of cytotrophoblast cells in culture remaining unrecognized [12].

To our knowledge, it is the first time that postculture media from primary cultures and one subculture of amniotic fluid cells from anencephalic fetuses have been analyzed for the presence of hormones. We found that hCG was released into the culture media confirming previous observations [16] that cells with appearance of AF cells and trophoblastic characteristics observed by cinemicrography, were present in amniotic fluid cultures from anencephalic fetuses.

The absence of PRL and P in the post-culture media, appearance and disappearance in both duplicate cultures of one amniotic fluid was interesting. Although PRL is synthesized by decidua and not by chorion or amnion [3], amnion light cells seem to selectively localize PRL [14]. The most probable origin of the prolactin in the post-culture media, due to the coexistence of tetraploidy, is amnion. However, the presence of decidual cells cannot be excluded.

Tetraploidy is relatively frequent in amniotic fluid cell cultures and has not received clinical importance [17] but recent reports of diploid/tetraploid mosaics $[20,23]$ render uncertain the interpretation of tetraploidy in amniotic fluid cell cultures. The presence of PRL might be useful, suggesting that the tetraploid cells originate from fetal membranes and not necessarily reflect the fetal karyotype. The presence of PRL in post-culture media would be of particular interest in the cultures of chorionic villi where maternal cell contamination by decidua is suspected [1].

Regarding $\mathrm{P}$, there is a previous report [18] that AF cells secrete $P$ into the nutrient medium; however, we found it in considerable amounts (74$140 \mathrm{ng} / \mathrm{ml}$ ) in the original amniotic fluid supernatants and not in the post-culture media with the exception of the already mentioned amniotic fluid
No. 1 from a normal fetus. Fetal membranes like amnion, chorion and decidua are capable of producing $P$ in a dose response relationship adding pregnenolone and in the case of amnion the area studied can affect the results [5]. Pregnenolone is not present in amniotic fluid cultures, so another source for $\mathrm{P}$ biosynthesis is cholesterol and in the absence of lipoprotein in the culture medium, the only source of cholesterol is the one previously stored within the cells or de novo cholesterol synthesis [22]. Therefore, the release of P and PRL to the post-culture media from amniotic fluid cells of amniotic fluid No. 1 cultures is most probably due to the presence of cells from fetal membranes.

LAUNDON et al [11] have proved that AF cells synthesize hCG, but more specific experiments with labeled aminoacids and immunocytochemistry will have to be performed regarding hCS, $\mathrm{P}$ and PRL production. Nevertheless, amniotic fluid cells cultured for prenatal diagnosis could extend their use in hormone studies, which are complicated by the absence of non-primate experimental models and ethical as well as functional limitations of in vivo studies. In vitro studies are more practical, despite the eternal debate of the extent to which these studies reflect the biosynthetic and regulatory pathways that occur in the normal placenta in vivo [8]. Of the in vitro studies, monolayer cultures provide certain advantages over organ cultures: replicate plates of dispersed cells provide less variation in cell number than fragmented tissue and thus give less variation in experimental results; organ cultures cannot be maintained as long as monolayers since tissue fragments tend to become necrotic due to inadequate difussion of nutrients, gases and metabolic products [6].

Amniotic fluid cell cultures used in prenatal diagnosis would give the following further advantages: no need for elaborate methods to culture cells from placenta; second trimester methods to culture cells from placenta; second trimester cells in contrast to the most frequently available and used third trimester cells; duplicate or triplicate cultures which can be used after karyotyping has been done and the possibility of cell cloning.

\begin{abstract}
Amniotic fluid cells have been widely used in prenatal diagnosis; however, there is great heterogeneity of the cells and their origin. In this study we analyze the karyotype and release of human chorionic gonadotropin (hCG), human chorionic somatomammotropin (hCS),
\end{abstract}

free estriol (E 3), prolactin (PRL) and progesterone (P) of amniotic fluid cells from primary cultures of six normal and two anencephalic fetuses. In all the amniotic fluid samples there was release of hCG; in one amniotic fluid, in which several tetraploid colonies were found, 
PRL and P were also released. The heterogeneity of amniotic fluid cell morphology and their hormone release in culture was confirmed. The presence of hormones like hCG supports the trophoblastic origin of some amniotic fluid cells from normal and anencephalic fetuses. Other hormones, such as PRL and P could be used in the differential diagnosis between the karyotype of fetal membranes and the true fetal karyotype. Amniotic fluid cell cultures used in prenatal diagnosis yielded second trimester placental cells without any elaborate methods that could be used as cell models for hormone studies.

Keywords: Amniotic fluid cells, hormone release, primary cultures.

\section{Zusammenfassung}

Hormonproduktion in primären Fruchtwasserzellkulturen In der pränatalen Diagnostik finden Langzeitkulturen von Fruchtwasserzellen breite Verwendung. Zellen aus der Amnionflüssigkeit von Feten ohne Neuralrohrdefekt (neural tube defect, NTD) werden morphologisch klassifiziert als epitheliale Zellen (E), Fibroblasten (F) oder Amnionzellen (AF). Bei Feten mit NTD können zusätzlich Neuroblasten $(\mathrm{N})$ und Gliazellen $(\mathrm{G})$ beobachtet werden. Fruchtwasserzellen haben unterschiedliche cytologische und biochemische Charakteristika, bedingt durch ihre unterschiedliche Herkunft. Untersuchungen an Zellkulturen bzw. deren Weiterkultivierung von Feten ohne NTD haben gezeigt, daß AF-Zellen humanes Choriongonadotropin (HCG) produzieren, während F-Zellen nicht dazu in der Lage sind $[10,11,18,19]$.

Ziel dieser Arbeit war die weitere Untersuchung der Hormonabgabe durch primäre Zellkulturen aus der Amnionflüssigkeit von normalen und anenzephalen Feten, um weitere Erkenntnisse über den Ursprung der Zellen zu erhalten und sie möglicherweise als Zellmodell bei Hormonuntersuchungen einzusetzen.

Wir kultivierten 8 Amnionflüssigkeiten mittels der in situ-Technik nach Amniozentese wegen Rhesusisoimmunisierung in 4 Fällen, anenzephalen Feten in 2 Fällen und cytogenetischer pränataler Diagnose in 2 Fällen. Der Karyotyp wurde durch Q- und G-Bandentechnik bestimmt, durch Weiterkultivierung sollten sich die Zellen noch vermehren und im Phasenkontrastmikroskop wurde die Morphologie der Zellen eingehend untersucht. Vor Beendigung der Kultur wurde das Zellmedium gesammelt (post-culture). Als Kontrollen dienten zum einen das Ausgangsmedium (pre-culture, Ham F $13+$ Penicillin/Streptomycin + Glutamin + Natriumbicarbonat $+30 \%$ fetales Kälberserum) sowie der Überstand aller originalen Fruchtwasserproben. Die Proben wurden verschlüsselt beschriftet und bis zur Versuchsdurchführung bei $-20^{\circ} \mathrm{C}$ eingefroren. Dann wurden im Blindversuch HCG, humanes Chorionsomatomammotrophin (HCS), freies Östriol $\left(E_{3}\right)$ Prolaktin (PRL) und Progesteron (P) bestimmt. Der Proteingehalt jeder Zellkultur wurde nach der Methode von Lowry gemessen [13].

Die Ergebnisse sind in den Tabellen I, II und III zusammengefaßt, wobei das Gestationsalter zum Zeitpunkt der Amniozentese, die Indikation, Gesamtdauer der Kultivierung, Alter der Kultur bis zur Probenentnahme der
Medien, morphologischer Zelltyp, Zellproteingehalt sowie die Hormonwerte berücksichtigt wurden. HCG wurde in allen Medien von primären Fruchtwasserzellkulturen normaler Feten gefunden sowie einschließlich im Medium bei einer balancierten Translokation und in 2 primären Kulturen bzw. einer Weiterkultivierung bei anenzephalen Feten. HCS oder $E_{3}$ ließen sich nicht nachweisen. PRL und $P$ fanden sich lediglich in einer primären Zellkultur eines normalen Feten, wo im Karyotyp zahlreiche tetraploide Kolonien Darstellbar waren.

Diese Ergebnisse bestätigen frühere Untersuchungen [10, 19], die ebenfalls eine große Variabilität bezüglich der HCG-Abgabe in Fruchtwasserproben beschreiben. Bei diploiden Kulturen waren die Schwankungen geringer. Die Abgabe von HCG durch Fruchtwasserzellen anenzephaler Feten bestätigt frühere Beobachtungen [16], die Zellen ähnlich den AF und cinemicrographisch bestimmten trophoblastischen Charakteristika beschreiben. AFZellen sollten weiter untersucht werden. Obwohl sie zur HCG-Abgabe fähig sind, ist kein HCS nachweisbar, was von der syncytialen Schicht synthetisiert wird. Dieser Verlust der Trophoblastzellen, in Langzeitkulturen HCS zu produzieren, wurde jedoch bereits früher beschrieben (24) und es scheint, daß AF-Zellen den Shift in der Hormonsynthese vom HCS zum HCG während einer intermittierenden Formation von Trophoblasten zu multinukleären Zellen widerspiegeln $[9,19]$.

Die Abgabe von P und PRL in einer primären Fruchtwasserzellkultur ist sehr wahrrscheinlich durch Zellen fetaler Membranen bedingt. Wir meinen, daß dieser Versuchsansatz zur Unterscheidung des Karyotyps fetaler Membranen vom echten fetalen Karyotyp hilfreich sein könnte. Man könnte das auch auf die Kutluren von Chorionville ausweiten, in denen eine Verunreinigung durch maternale Zellen vermutet wird.

Weiterhin können Fruchtwasserzellkulturen als Modelle für Hormonuntersuchungen benutzt werden, und zwar mit folgenden Vorteilen: es brauchen keine Methoden zur Kultivierung von Plazentazellen ausgearbeitet $\mathrm{zu}$ werden, man hat Zellen aus dem zweiten Trimenon im Gegensatz zu den weit häufiger verfügbaren und eingesetzten Zellen aus dem dritten Trimenon, nach Karyotypisierung kann man diploide und triploide Kulturen und die Möglichkeit zum Zellklonen schaffen.

Schlüsselwörter: Fruchtwasserzellen, Hormonabgabe, primäre Kulturen. 


\section{Résumé \\ Libération hormonale par cultures primaires de cellules du liquide amniotique}

Pour le diagnostic prénatal on a largement utilisé les cultures à long terme de cellules du liquide amniotique. Par étude morphologique on a classé les cellules du liquide amniotique en provenance de fœtus sans défect du tube neural (NTD) en épithéliales (E), fibroblastes (F) et liquide amniotique (AF); en plus de ces cellules, chez le foetus avec NTD on observe des neuroblasses $(N)$ et des cellules gliales (G) ]16]. Les cellules du liquide amniotique ont des cractéristiques cytologique et biochimiques différentes ce qui suggére des origines différentes. Les études réalisées sur les cellules du liquide amniotique en provenance de fœtus sans NTD et principalement en sous-cultures ont montré que les cellules $\mathrm{AF}$ synthétisent de la gonadotrophine chorionique humaine (HCG) alors que les cellules F n'en synthétisent pas $[10,11,18,19]$.

L'objectif de ce travail a été de mieux caractériser la libération hormonale par cultures primaires de cellules du liquide amniotique en provenance de fotus normaux et d'anencéphales afin d'explorer leur origine et leur utilisation potentielle comme modèles d'études des hormones.

8 liquides amniotiques ont été mis en culture par la tehnique in situ, ces liquides ont été obtenu par amniocentèse réalisée pour iso-immunisation rhésus (4), anencéphalies (2) et diagnostic cytogénétique prénatal (2).

Pour tous les liquiedes amniotiques, le caryotype a été obtenu par banding $Q$ et $G$, les cultures primaires ont été poursuivies en essayant d'obtenir une confluence et la morphologie des cellules a été déterminée au microscope à contraste de phase. Les milieux de culture cellulaire (post culture) ont été collectés avant la fin de la culture. On a utilisé comme contrôles, les milieux de préculture (HAM F12 + peniciline/streptomycine + glutamine + bicarbonate de sodium $+30 \%$ de sérum de veau fotal) et le surnageant de tous les liquides amniotiques originaux. Les échantillons ont été codés et stockés à $-20^{\circ} \mathrm{C}$ jusqu'à ce que le dosages soient réalisés dans un essai à l'aveugle afin de mesurer L'HCG, la sormatotrophine chorionique humaine (HCS), l'estriol libre (E3), la prolactine (PRL) et la progesterone (P). Les proteines cellulaires pour chaque culture ont été quantifiées par la méthode de LOV [13].

Les résultats sont résumés dans les tableaux I, II, III selon l'âge au moment de l'amniocentèse, la raison de l'amniocentèse, le nombre total de jours de culture, les jours en culture avant que les milieux soient prélevés, le typage morphologique des cellules, les proteines-cellu- laires et les valeurs hormonales. L'HCG a été libérée dans les milieux de toutes les cultures primaires de liquide amniotique en provenance des fetus normaux y compris les cellules avec translocation équilibrée ainsi que 2 cultures primaires et une sous culture en provenance de fœtus anencéphalés.

Il n'y a pas eu de libération ni d'HCS ni de E3. La PRL et la $\mathbf{P}$ n'ont été libérés que dans une culture primaire de cellules du liquide amniotique en provenance d'un fotus normal: liquide dans lequel les cellules caryotypées ont révélé plusieurs colonies tétraploïdes.

Les résultats on confirmé les données antérieures [10, 19], à savoir la grande variabilité de la libération d'HCG d'un liquide amniotique à un autre mais une plus grande uniformité pour les culture dupliquées. La libération d'HCG par les cellules du liquide amniotique en provenance de fœtus anencéphales confirme les observations antérieures [16] de cellules ayant l'apparence de AF et des caractéristiques trophoblastiques en cinémicrographie. Les résultats fournissent des informations supplémentaires concernant les cellules AF.

Bien qu'ayant la capacité de libérer HCG, elles ne libèrent pas d'HCS qui est synthétisée par la couche syncytiale. Néanmoins, la perte de la production d'HCS par les cultures prolongées de cellules trophoblastiques a été décrite auparavant [24] et il semble que les cellules $\mathrm{AF}$ reflètent le changement au niveau de la synthèse hormonale de l'HCS à l'HCG au cours de la formation de cellules trophoblastiques intermédiaires multinuclées $[9,19]$.

La libération de $P$ et de PRL dans une culture primaire de liquide amniotique est très vraissemblabement secondaire à la présence de cellules provenant des membranes fœetales Nous suggérons que le dosage de ces hormones dans les cultures pourrait aider au diagnostic différentiel entre le caryotype de membranes fotales et le caryotype fotal réel. Cela pourrait être étendu aux cultures de villosités choriales dans lesquelles une contamination par les cellules maternelles par la décidua est suspectée.

$\mathrm{Au}$ total, les cultures des cellules du liquide amniotique pourraint être d'avantage utilisées comme modèles cellulaires pour les études hormonales, en offrant les avantages suivants:

Pas de necessité d'élaborer des méthodes de culture des cellules provenant du placenta, études des cellules, du second trimestre ce qui contraste avec les cellules du troisième trimestre plus frequemment disponibles et utilisées, cultures dupliquées ou triplées qui peuvent être utilisées après que le caryotype ait été effectué ainsi que la possibilité de clonage cellulaire.

Mots-clés: Cellules du liquide amniotique, cultures primaires, libération hormonale. 


\section{References}

[1] Carey WF, EF Robertson, C van Crutgen, A Poulos, PJ Nelson, G Finikiotis: Prenatal diagnosis of Zellweger's syndrome by chorionic villus sampling and a caveat. Pren Diagn 6 (1986) 227

[2] Cremer M, I Treiss, T Cremer, D Hager, WW FRANKE: Characterization of amniotic fluids by immunological identification of intermediate-sized filaments: presence of cells of different tissue origin. Hum Genet 59 (1981) 373

[3] DE ZieGLeR D, E GURPIDE: Production of prolactin by cultures of cells from human decidua. $\mathrm{J}$ Clin Endocrinol Metab 55 (1982) 511

[4] Gerbie AB, SB Melancon, G Ryan, HL Nadler: Cultivated epithelial like cells and fibroblasts from amniotic fluid: their relationship to enzymatic and cytologic analysis. Am J Obstet Gynecol 14 (1972) 314

[5] GibB W, JC LavoIE, J Roux: In vitro conversion of pregnenolone to progesterone by term human fetal membranes. Am J Obstet Gynecol 136 (1980) 631

[6] Goldsmith LT, M Essig, P Sarosi, P Beck, G WeIss: Hormone secretion by monolayer cultures of human luteal cells. J Clin Endocrinol Metab 53 (1981) 890

[7] HaNdWerger S, PM Conn, J BARret, S Barry, A GOLANDER: Human placental lactogen release in vitro: paradoxical effects of calcium. Am J Physiol 240 (1981) E 550

[8] Hussa RO: Biosynthesis of human chorionic gonadotropin. Endocr Rev 1 (1980) 268

[9] Kurman RJ, RH Young, HJ Norris, CS MaIN, WD LAWRENCE, RE SCULLY: Immunocytochemical localization of placental lactogen and chorionic gonadotropin in normal placenta and trophoblastic tumours, with emphasis on intermediate trophoblast and the placental site trophoblastic tumor. Int J Gynecol Pathol 3 (1984) 101

[10] Laundon CH, JH Priest, RE Priest: Characterization of hCG regulation in cultured human amniotic fluid cells. Pren Diagn 1 (1981) 269

[11] Laundon CH, JH PrIest, RE Priest: Characterization of hCG regulation in cultured human amniotic fluid cells. II. Mechanism for stimulation. In Vitro 19 (1983) 911

[12] LOKe YW, BH Butterworth, JJ Margetts, K BURLAND: Identification of cytotrophoblast colonies in culture of human placental cells using monoclonal antibodies. Placenta 7 (1986) 221

[13] LOWRY HO, NJ Rosenbrough, AL FARR, RJ RANDALL: Protein measurement with the folin phenol reagent. J Biol Chem 193 (1951) 265
[14] Mc Coshen JA, K Tomita, C Fernandez, JE TYSON: Specific cells of human amnion selectively localize prolactin. J Clin Endocrinol Metab 55 (1982) 166

[15] Mc Williams D, I Boime: Cytological localization of placental lactogen messenger ribonucleic acid in syncytiotrophoblast layers of human placenta. Endocrinol 107 (1980) 761

[16] Medina-Gomez P, JBL BARD: Analysis of normal and abnormal amniotic fluid cells in vitro by cinemicrography. Pren Diagn 3 (1983) 311

[17] Milunsky A, L AtKins, J LitTlefield: Polyploidy in prenatal genetic diagnosis. J Paediatr 79 (1971) 303

[18] Priest RE, JH PrIEst: Specialized functions and origins of cultured cells from human amniotic fluid. In Vitro 16 (1980) 243

[19] Priest RE, JH Priest, JF Moinuddin, DS SGouTAS: Differentiation in human amniotic fluid cell cultures; chorionic gonadotropin production. In Vitro 15 (1979) 142

[20] Quiroz E, A Orozco, F Salamanca: Diploidtetraploid mosaicism in a malformed boy. Clin Genet 27 (1985) 183

[21] von Koskull H, P Aula, LK Trejdosiewics, I VIRTANEN: Identification of cells from fetal bladder epithelium in human amniotic fluid. Hum Genet 65 (1984) 262

[22] Winkel CA, JM SNyder, PC Mac Donald, ER SIMPSON: Regulation of cholesterol and progesterone synthesis in human placental cells in culture serum lipoproteins. Endocrinol 106 (1980) 1054

[23] WitTwer BB, HB WitTwer: Information about diploidtetraploid mosaicism in a six-year old male. Clin Genet 28 (1985) 567

[24] Zeitler P, E Markoff, S Handwerger: Characterization of the synthesis and release of human placental lactogen and human chorionic gonadotropin by an enriched population of dispersed placental cells. J Clin Endocrinol Metab 57 (1983) 812

Received April 27, 1988. Accepted May 16, 1988.

Dr. Antonio Espinosa de los Monteros

Departamento de Endocrinología

Instituto Nacional de Perinatología

Montes Urales 800

Col. Lomas Virreyes

11000 México, D. F., México 